\title{
Electric field induced surface passivation of Si by atomic layer deposited Al2O3 studied by optical second-harmonic generation
}

Citation for published version (APA):

Kessels, W. M. M., Gielis, J. J. H., Hoex, B., Terlinden, N. M., Dingemans, G., Verlaan, V., \& Sanden, van de, M. C. M. (2009). Electric field induced surface passivation of $\mathrm{Si}$ by atomic layer deposited Al2O3 studied by optical second-harmonic generation. In Proceedings of the 34th IEEE Photovoltaic Specialist Conference (PVSC 2009) 7-12 June 2009 Philadelphia, USA (pp. 000427-000431-). Institute of Electrical and Electronics Engineers. https://doi.org/10.1109/PVSC.2009.5411651

DOI:

10.1109/PVSC.2009.5411651

Document status and date:

Published: 01/01/2009

Document Version:

Publisher's PDF, also known as Version of Record (includes final page, issue and volume numbers)

Please check the document version of this publication:

- A submitted manuscript is the version of the article upon submission and before peer-review. There can be important differences between the submitted version and the official published version of record. People interested in the research are advised to contact the author for the final version of the publication, or visit the $\mathrm{DOI}$ to the publisher's website.

- The final author version and the galley proof are versions of the publication after peer review.

- The final published version features the final layout of the paper including the volume, issue and page numbers.

Link to publication

\footnotetext{
General rights

- You may freely distribute the URL identifying the publication in the public portal. follow below link for the End User Agreement:

www.tue.nl/taverne

Take down policy

If you believe that this document breaches copyright please contact us at:

openaccess@tue.nl

providing details and we will investigate your claim.
}

Copyright and moral rights for the publications made accessible in the public portal are retained by the authors and/or other copyright owners and it is a condition of accessing publications that users recognise and abide by the legal requirements associated with these rights.

- Users may download and print one copy of any publication from the public portal for the purpose of private study or research.

- You may not further distribute the material or use it for any profit-making activity or commercial gain

If the publication is distributed under the terms of Article 25fa of the Dutch Copyright Act, indicated by the "Taverne" license above, please 


\section{Electric field induced surface passivation of $\mathrm{Si}$ by atomic layer deposited $\mathrm{Al}_{2} \mathrm{O}_{3}$ studied by optical second-harmonic generation}

W.M.M. Kessels, J.J.H. Gielis, B. Hoex, ${ }^{*}$ N.M. Terlinden, G. Dingemans, V. Verlaan, and M.C.M. van de Sanden Dept. of Applied Physics, Eindhoven Univ. of Technology, P.O. Box 513, 5600 MB Eindhoven, The Netherlands

\section{ABSTRACT}

Recently, we have demonstrated that ultrathin $(<30$ $\mathrm{nm}$ ) films of $\mathrm{Al}_{2} \mathrm{O}_{3}$ synthesized by (plasma-assisted) atomic layer deposition (ALD) provide an excellent level of surface passivation of $c$-Si which may find important applications in (high-efficiency) solar cells. In this contribution, the $\mathrm{Al}_{2} \mathrm{O}_{3}$ passivation mechanism has been further elucidated by the contactless characterization of the $c-\mathrm{Si} / \mathrm{Al}_{2} \mathrm{O}_{3}$ interface by optical second-harmonic generation (SHG). SHG has revealed effective field-effect passivation of the $c$-Si surface caused by a negative fixed charge density of $5 \times 10^{12} \mathrm{~cm}^{-2}$ in an annealed, $11 \mathrm{~nm}$ thick $\mathrm{Al}_{2} \mathrm{O}_{3}$ film while it is on the order of $10^{11} \mathrm{~cm}^{-2}$ in the as-deposited film which shows negligible passivation. A comparison with SHG measurements on a $84 \mathrm{~nm}$ thick $a-\mathrm{SiN}_{x}: \mathrm{H}$ film treated in a conventional firing furnace has revealed the presence of a positive fixed charge density of $2 \times 10^{12} \mathrm{~cm}^{-2}$ which further corroborates the SHG analysis and results.

\section{INTRODUCTION}

Due to the decrease of wafer thickness in crystalline silicon (c-Si) photovoltaics, the surface-to-bulk ratio of solar cells increases. This enhances the need of good surface passivation for both the front and rear side of the c-Si solar cells. In general, surface passivation can be induced $(i)$ by reducing the amount of recombination centers at the interface (so-called chemical passivation), and (ii) by electrostatic shielding the charge carriers from the interface by an internal electric field (so-called field-effect passivation). Several thin films applied to the $c$-Si surface have shown to obtain a good degree of surface passivation by employing (i) or (ii) or by a combination of both.

Recently, excellent surface passivation by $\mathrm{Al}_{2} \mathrm{O}_{3}$ films synthesized by (plasma-assisted) atomic layer deposition (ALD) has been reported for $n, p$ and $p^{+}$type $c$-Si $[1,2,3,4]$. These results were obtained after a post-deposition anneal as the $\mathrm{Al}_{2} \mathrm{O}_{3}$ films demonstrated no significant level of surface passivation in the as-deposited state. The surface passivation properties by $A L D$-synthesized $\mathrm{Al}_{2} \mathrm{O}_{3}$ films were also confirmed at the device level. $\mathrm{Al}_{2} \mathrm{O}_{3}$ applied at the rear of diffused emitter $p$-type $c$-Si solar cells yielded a conversion efficiency of $20.6 \%$ [5] and $\mathrm{Al}_{2} \mathrm{O}_{3}$ applied for boron doped emitter passivation at the front side of $n$-type c-Si solar cells yielded a conversion efficiency of $23.2 \%$ [6].

The passivation properties of $\mathrm{Al}_{2} \mathrm{O}_{3}$ films are related to negative fixed charge in $\mathrm{Al}_{2} \mathrm{O}_{3}$ leading to an internal electrical field at the c-Si interface and therefore providing field-effect passivation $[7,8]$. Characterization of the fieldeffect passivation and the fixed charge density in the $\mathrm{Al}_{2} \mathrm{O}_{3}$ films before and even during processing could help to further unravel the passivation mechanism. In this respect, the noninvasive nonlinear optical technique of secondharmonic generation ( $\mathrm{SHG}$ ) is a very promising diagnostic. SHG, as schematically illustrated in Fig. 1, is highly interface sensitive for centrosymmetric media and allows for a contactless detection of internal electric fields, which can either be applied static fields or electric fields in semiconductor space-charge regions arising from interfacial charge separation $[9,10]$. The effect of electric fieldinduced SHG (EFISH) can be described by the secondorder nonlinear polarization $\mathbf{P}^{(2)}(2 \omega)$ induced by an incident electric field $\mathbf{E}(\omega)$

$$
\mathbf{P}^{(2)}(2 \omega)=\varepsilon_{0} \vec{\chi}_{B}^{(3)}(2 \omega): \mathbf{E}(\omega) \mathbf{E}(\omega) \mathbf{E}_{d c, \text { bulk }},
$$

where $\vec{\chi}_{B}^{(3)}$ and $\mathbf{E}_{d c, \text { bulk }}$ are the third-order nonlinear susceptibility tensor and dc electric field, respectively. EFISH has been used to study charge trapping in the $c-\mathrm{Si} / \mathrm{SiO}_{2}$ system $[11,12,13,14]$, photon induced charge trapping $[15,16]$, as well as process-dependent charging in high- $\kappa$ dielectric stacks $[17,18]$.

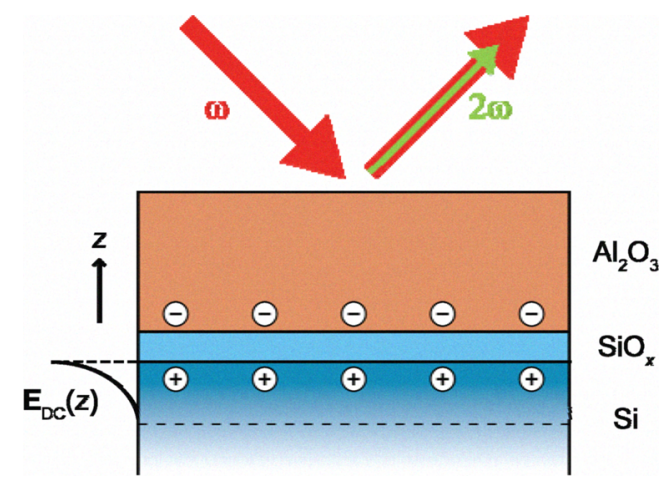

Fig. 1. Schematic representation of the second harmonic generation (SHG) method used to measure the electric field in the space charge region of $\mathrm{C}-\mathrm{Si}$ as caused by the presence of fixed negative interface charge in the $\mathrm{Al}_{2} \mathrm{O}_{3}$ film. The method, sensitive to electric fields of $>10^{5} \mathrm{~V} / \mathrm{cm}$, is also referred to as electric field induced second harmonic generation or EFISH. SHG can be considered as the conversion of two photons with energy $\hbar \omega$ into a single photon of energy $2 \hbar \omega$, a process that can occur only for high intensity (laser) radiation. 


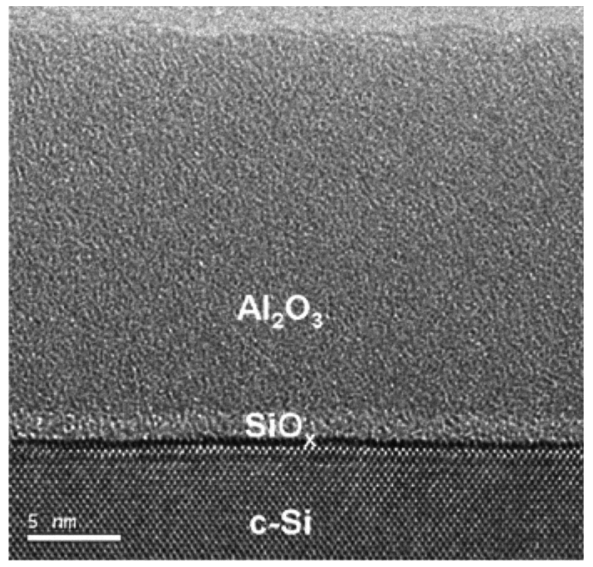

Fig. 2. High resolution transmission electron micrograph (HR-TEM) of an ALD-synthesized $\mathrm{Al}_{2} \mathrm{O}_{3}$ film ( $20 \mathrm{~nm}$ thick) yielding excellent $\mathrm{Si}$ surface passivation after a postdeposition anneal. The interfacial $\mathrm{SiO}_{\mathrm{x}}$ is $\sim 1.5 \mathrm{~nm}$ thick [3].

In this paper we characterize as-deposited and annealed $\mathrm{Si}(100) / \mathrm{Al}_{2} \mathrm{O}_{3}$ structures with interfacial $\mathrm{SiO}_{x}$ synthesized by plasma-assisted ALD using spectroscopic SHG [19]. The results are compared with SHG results obtained on an a-SiN $\mathrm{N}_{\mathrm{x}}: \mathrm{H}$ film deposited with plasmaenhanced chemical vapor deposition (PECVD). The polarity of the fixed charges is confirmed to be negative for the $\mathrm{Al}_{2} \mathrm{O}_{3}$ and positive for the a-SiN $\mathrm{x}: \mathrm{H}$. The fixed charge density is also deduced for both materials and it is shown that the density exhibits a strong increase after anneal for the $\mathrm{Al}_{2} \mathrm{O}_{3}$, from a value lower than for $\mathrm{a}-\mathrm{SiN}_{\mathrm{x}}: \mathrm{H}$ before anneal to a value significantly higher than for $a-\mathrm{SiN}_{\mathrm{x}}: \mathrm{H}$ after anneal. These results provide important insight into the interface passivation properties of $\mathrm{Al}_{2} \mathrm{O}_{3}$ and directly illustrate the feasibility of SHG as a contactless technique to characterize field-effect surface passivation of $c$-Si in situ and during processing.

\section{EXPERIMENTAL}

Amorphous $\mathrm{Al}_{2} \mathrm{O}_{3}$ films were deposited at both sides of $275 \mu \mathrm{m}$ thick $\mathrm{P}$-doped $\mathrm{H}$-terminated Si(100) wafers with a resistivity of $1.9 \Omega \mathrm{cm}$ by plasma-assisted ALD using alternating $\mathrm{Al}\left(\mathrm{CH}_{3}\right)_{3}$ dosing and $\mathrm{O}_{2}$ plasma exposure at a substrate temperature of $200^{\circ} \mathrm{C}$. After being analyzed, the as-deposited samples were annealed for $30 \mathrm{~min}$ at $425^{\circ} \mathrm{C}$ in $\mathrm{N}_{2}$. More details on the preparation of the $\mathrm{Al}_{2} \mathrm{O}_{3}$ films and their analysis, demonstrating for example a atomic composition of $[\mathrm{O}] /[\mathrm{Al}]=1.5$, a $\mathrm{H}$-content of 2 at.\% and a refractive index of 1.62 at $2 \mathrm{eV}$, can be found in Ref. 20. High resolution transmission electron microscopy (HRTEM) images, such as shown in Fig. 2, revealed the presence of an interfacial $\mathrm{SiO}_{\mathrm{x}}$ layer of $\sim 1.5 \mathrm{~nm}$ between the $\mathrm{Si}(100)$ and the $\mathrm{Al}_{2} \mathrm{O}_{3}$ both before and after anneal, with the $\mathrm{Al}_{2} \mathrm{O}_{3}$ remaining amorphous after anneal [3]. With carrier lifetime spectroscopy the effective lifetimes of $c$-Si passivated by as-deposited $\mathrm{Al}_{2} \mathrm{O}_{3}$ were determined to be <
$10 \mu \mathrm{s}$, which are indistinguishable from an unpassivated $c-$ Si wafer, whereas after anneal lifetimes up to $6.6 \mathrm{~ms}$ were obtained, corresponding to an excellent level of surface passivation $[3,4,7]$.

An a-SiN $\mathrm{x}$ : $\mathrm{H}$ film deposited by PECVD in the OTB Solar DEPx system from an $\mathrm{Ar}-\mathrm{NH}_{3}-\mathrm{SiH}_{4}$ gas mixture was used for comparison purposes. This film, $84 \mathrm{~nm}$ thick and with a refractive index of 2.1 at $2 \mathrm{eV}$, was deposited on a $380 \mu \mathrm{m}$ thick B-doped $\mathrm{H}$-terminated $\mathrm{Si}(100)$ wafer with a resistivity of $8.4 \Omega \mathrm{cm}$. The sample underwent a hightemperature $\left(\sim 800^{\circ} \mathrm{C}\right)$ firing step in a standard metallization firing furnace. More details are described in Ref. [21]. The effective lifetime of $c$-Si passivated by the a-SiN ${ }_{x}: H$ was determined to be $174 \mu$ s with carrier lifetime spectroscopy (as measured right before the SHG experiments).

The SHG experiments were carried out at an angle of incidence of $35^{\circ}$ using a Ti:sapphire oscillator providing radiation tunable in the $1.33-1.75 \mathrm{eV}$ photon energy range with a pulse duration of $\sim 90 \mathrm{fs}$ [22]. Data were obtained at $p$-polarized fundamental and SHG radiation using a laser power at the sample of $40 \mathrm{~mW}$ (fluence $25 \mu \mathrm{J} \mathrm{cm}^{-2}$ per pulse).

\section{RESULTS AND DISCUSSION}

In Fig. 3(a) and (b) SHG spectra for p-polarized fundamental and SHG radiation are shown for the $11 \mathrm{~nm}$ thick $\mathrm{Al}_{2} \mathrm{O}_{3}$ film on $\mathrm{Si}(100)$, as-deposited and after anneal, respectively. Both show a distinct resonance in the $3.3-3.4$ $\mathrm{eV}$ range, indicating that the SHG response is dominated by $c$-Si interband transitions at the $E_{0} / E_{1}$ critical point (CP) $[23,24]$. The anneal very clearly modifies the SHG spectrum; the amplitude increases with more than an order of magnitude, whereas the peak shifts from $\sim 3.3$ to $\sim 3.4 \mathrm{eV}$ resulting in a more symmetric feature.

In order to separate different contributions to the SHG response, the spectra have been reproduced using a model in which the SHG intensity is approximated by a coherent superposition of CP-like resonances with excitonic line shapes evaluated at the substrate/film interface $[22,25,26]$

$$
\begin{aligned}
I(2 \omega) & =\left|A_{z z z}(\omega, \theta) \sum_{q} \chi_{z z z, q}^{(2)}\right|^{2} l_{\text {in }}^{2}(\omega) \\
& \propto\left|A_{z z z}(\omega, \theta) \sum_{q} \frac{h_{q} e^{i \varphi_{q}}}{2 \omega-\omega_{q}+i \Gamma_{q}}\right|^{2} l_{\text {in }}^{2}(\omega),
\end{aligned}
$$

where $h_{q}$ denotes the (real) amplitude, $\omega_{q}$ the frequency, $\Gamma_{q}$ the linewidth, and $\varphi_{q}$ the excitonic phase of resonance $q$. The spectra have been analyzed in terms of tensor element $\chi_{z z z}^{(2)}$, as including the other elements contributing to $p$-polarized fundamental and SHG radiation, $\chi_{z \times x}^{(2)}$ and $\chi_{x x z}^{(2)}$ [9], does not modify the spectral parameters significantly. The complex function $A_{z z z}(\omega, \theta)$ in Eq. (2) describes the propagation of the fundamental and SHG radiation in the film-substrate system. This film thickness dependent function includes linear optical effects, such as 
absorption, refraction, and interference due to multiple reflections within the $\mathrm{Al}_{2} \mathrm{O}_{3}$ films [22].

The spectrum for the as-deposited $\mathrm{Al}_{2} \mathrm{O}_{3}$ film clearly has an asymmetric shape, indicating the presence of multiple interfering contributions. The data can be fitted very well when taking into account three contributions with their parameters listed in Table I. The individual resonances, shown in Fig. 3(a), consist of a main contribution at $3.32 \pm$ $0.01 \mathrm{eV}$ and additional contributions at $3.38 \pm 0.01 \mathrm{eV}$ and $3.62 \mathrm{eV}$. The resonance frequency and linewidth of the third contribution are fixed at 3.62 and $0.36 \mathrm{eV}$, as within the current experimental photon energy range the parameters of this contribution can not be determined unambiguously. These latter values have been reported by Rumpel et al. for $c-\mathrm{Si} / \mathrm{SiO}_{2}$ and have been attributed to a resonance related to $\mathrm{Si}$ interband transitions in a thin transition layer between $\mathrm{Si}$ and $\mathrm{SiO}_{2}[27,28]$. The presence of such an interface resonance seems also viable for the $\mathrm{Si} / \mathrm{Al}_{2} \mathrm{O}_{3}$ system, especially considering the presence of the interfacial $\mathrm{SiO}_{x}$ layer as detected by HR-TEM (Fig. 2). Also, the parameters of the resonances at $3.32 \pm 0.01 \mathrm{eV}$ and 3.38 $\pm 0.01 \mathrm{eV}$ correspond well to values reported for the $c-\mathrm{Si} / \mathrm{SiO}_{2}$ interface [28], as well as to values reported for clean and $\mathrm{H}$ dosed $c$-Si surfaces [24]. In addition to the good reproduction of the experimental data, this similarity supports the validity of the fitting results.

Moreover, the SHG spectrum after anneal can also be reproduced very well by the same resonances, as shown in Table I and Fig. 3(b). The second contribution at 3.414 $\pm 0.004 \mathrm{eV}$ is clearly dominant with an amplitude that increased by a factor of six compared to the as-deposited sample. The first contribution has redshifted to $3.25 \pm 0.02$ $\mathrm{eV}$ and has minor impact. This contribution can be assigned to interband transitions related to Si-Si bonds modified due to the vicinity of the interface with the film $[23,24]$. The redshift of this "modified Si-Si interface contribution" after anneal might be related to further weakening of Si-Si bonds $[23,27]$, indicating structural changes in the (interfacial) oxide.
The resonance around $3.40 \mathrm{eV}$ is a clear signature of EFISH originating from the bulk space-charge region (SCR) in the $c$-Si [24]. The Si SCR is predominantly caused by fixed charge in the $\mathrm{Al}_{2} \mathrm{O}_{3}$, as schematically illustrated in Fig. 1. The drastic increase of the EFISH contribution after anneal is a clear indication for the increase of the fixed charge density $Q_{f}$ in the $\mathrm{Al}_{2} \mathrm{O}_{3}$. The electric field at the interface with $\mathrm{Al}_{2} \mathrm{O}_{3}$ resulting from the doping of the c-Si substrates $\left(2.5 \times 10^{15} \mathrm{~cm}^{-3}\right)$ can be estimated to be < $10 \mathrm{kV} \mathrm{cm}^{-1}[29,30]$, which is too low to have a significant effect on the SHG response [10,24]. As shown in Table I, the phase difference between the contribution due to the Si-Si interface bonds and the EFISH contribution is $\sim \pi$, both before and after anneal, which indicates a positively charged Si SCR [28], and thus negative fixed charge in the $\mathrm{Al}_{2} \mathrm{O}_{3}$. Electrical characterization of $\mathrm{Al}_{2} \mathrm{O}_{3}$ films has revealed the presence of negative fixed charge situated predominantly at the interface with interfacial $\mathrm{SiO}_{x}[8,31,32]$.

The intensity of the EFISH contribution resulting from the $C P$ modeling reflects the magnitude of the electric field $E_{z}^{D C}(z)$ in the Si SCR and can be used to quantify the negative $Q_{f}$ in the $\mathrm{Al}_{2} \mathrm{O}_{3}$ before and after anneal. To achieve this, the negative $Q_{f}$ can be related to the electric field $E_{z}^{D C}(z)$ in the Si SCR by numerically integrating Poisson's equation. Subsequent integration of $E_{z}^{D C}(z)$ over the SCR, taking into account the penetration and escape depths of the fundamental and SHG radiation, gives the EFISH electric field and, hence, the EFISH intensity $[10,24]$

$$
I^{\mathrm{EFISH}}(2 \omega) \sim\left|\vec{\chi}^{(3)}: \mathrm{E}(\omega) \mathrm{E}(\omega) \int_{-\infty}^{0} \mathrm{e}^{-i\left(K_{z}+2 k_{z}\right) z} E_{z}^{\mathrm{DC}}(z) d z\right|^{2},
$$

where $K_{z}$ and $k_{z}$ are the complex wavevector components of the SHG and fundamental radiation perpendicular to the $c$-Si/ $/ \mathrm{Al}_{2} \mathrm{O}_{3}$ interface, respectively. To relate the $\mathrm{EFISH}$ intensity to absolute values of $Q_{f}$ in the $\mathrm{Al}_{2} \mathrm{O}_{3}$, a $26 \mathrm{~nm}$ annealed $\mathrm{Al}_{2} \mathrm{O}_{3}$ film on $\mathrm{Si}(100)$ with a known negative

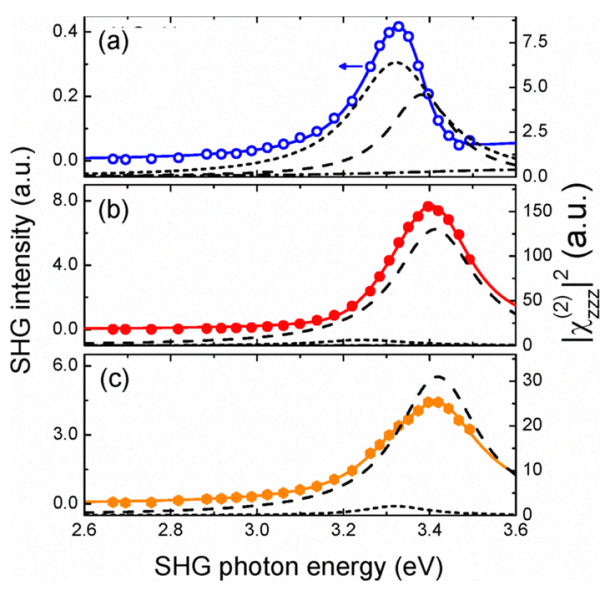

Fig. 3. SHG spectra for (a) an $11 \mathrm{~nm}$ as-deposited $\mathrm{Al}_{2} \mathrm{O}_{3}$ film on $\mathrm{Si}(100)$, (b) an $11 \mathrm{~nm}$ annealed $\mathrm{Al}_{2} \mathrm{O}_{3}$ film on $\mathrm{Si}(100)$, and (c) an $84 \mathrm{~nm}$ "fired" a-SiN $\mathrm{x}: \mathrm{H}$ film on $\mathrm{Si}(100)$. The solid lines are fits to the data using a superposition of two or three CP-like resonances. The dashed lines represent the individual resonances. Note the difference in vertical scale. 
Table I. Parameters of the critical point resonances as obtained from the fits to the SHG spectra for the passivation films deposited on $\mathrm{Si}(100): 11 \mathrm{~nm} \mathrm{Al}_{2} \mathrm{O}_{3}$ as-deposited and after anneal, and $84 \mathrm{~nm}$ a-SiN $\mathrm{N}_{\mathrm{x}}: \mathrm{H}$ after "firing". In the analysis $\varphi_{1}$ is set to 0 . Parameter values in italic were fixed in the analysis.

\begin{tabular}{|c|c|c|c|c|c|c|c|c|c|c|c|}
\hline \multirow[t]{2}{*}{ Sample } & \multicolumn{3}{|c|}{ Modified Si-Si interface contribution } & \multicolumn{4}{|c|}{ EFISH contribution } & \multicolumn{4}{|c|}{ Oxide related interface contribution } \\
\hline & $\begin{array}{l}\mathrm{h}_{1} \\
\text { (arb. units) }\end{array}$ & $\begin{array}{l}\hbar \omega_{1} \\
(e V)\end{array}$ & $\begin{array}{l}\mathrm{h} \Gamma_{1} \\
(\mathrm{eV})\end{array}$ & $\begin{array}{c}h_{2} \\
\text { (arb. units) }\end{array}$ & $\begin{array}{l}\hbar \omega_{2} \\
(e V)\end{array}$ & $\begin{array}{l}\mathrm{h} \Gamma_{2} \\
(\mathrm{eV})\end{array}$ & $\begin{array}{c}\varphi_{2} \\
(\pi \mathrm{rad})\end{array}$ & $\begin{array}{c}h_{3} \\
\text { (arb. units) }\end{array}$ & $\begin{array}{l}\hbar \omega_{3} \\
(\mathrm{eV})\end{array}$ & $\begin{array}{l}\mathrm{h} \Gamma_{3} \\
(\mathrm{eV})\end{array}$ & $\begin{array}{c}\varphi_{3} \\
(\pi \mathrm{rad})\end{array}$ \\
\hline $\begin{array}{c}\mathrm{Al}_{2} \mathrm{O}_{3} \\
\text { as-dep. }\end{array}$ & $\begin{array}{c}0.31 \\
\pm 0.05\end{array}$ & $\begin{array}{c}3.32 \\
\pm 0.01\end{array}$ & $\begin{array}{c}0.121 \\
\pm 0.009\end{array}$ & $\begin{array}{c}0.19 \\
\pm 0.07\end{array}$ & $\begin{array}{c}3.38 \\
\pm 0.01\end{array}$ & $\begin{array}{c}0.09 \\
\pm 0.01\end{array}$ & $\begin{array}{c}0.9 \\
\pm 0.1\end{array}$ & $\begin{array}{c}0.23 \\
\pm 0.12 \\
\end{array}$ & 3.62 & 0.36 & $\begin{array}{c}0.33 \\
\pm 0.07\end{array}$ \\
\hline $\begin{array}{c}\mathrm{Al}_{2} \mathrm{O}_{3} \\
\text { anneal }\end{array}$ & 0.31 & $\begin{array}{c}3.25 \pm \\
0.02\end{array}$ & 0.121 & $\begin{array}{c}1.21 \\
\pm 0.05\end{array}$ & $\begin{array}{c}3.414 \\
\pm 0.004\end{array}$ & $\begin{array}{c}0.114 \\
\pm 0.004\end{array}$ & $\begin{array}{c}1.00 \\
\pm 0.06\end{array}$ & 0.23 & 3.62 & 0.36 & 0.33 \\
\hline $\begin{array}{c}\text { a-SiN }{ }_{x}: H \\
\text { "fired" }\end{array}$ & $\begin{array}{c}0.13 \\
\pm 0.02\end{array}$ & $\begin{array}{c}3.32 \\
\pm 0.01\end{array}$ & $\begin{array}{c}0.090 \\
\pm 0.008\end{array}$ & $\begin{array}{c}0.65 \\
\pm 0.03\end{array}$ & $\begin{array}{c}3.419 \\
\pm 0.007\end{array}$ & $\begin{array}{c}0.116 \\
\pm 0.004\end{array}$ & $\begin{array}{c}0.01 \\
\pm 0.03\end{array}$ & - & - & - & - \\
\hline
\end{tabular}

$Q_{f}$ of $(1.3 \pm 0.1) \times 10^{13} \mathrm{~cm}^{-2}$, as measured in a corona charging experiment was used for calibration $[7,19]$. This value of $Q_{f}$ yields an electric field at the position of the interface of $E_{z}^{D C}(0)=2.1 \mathrm{MV} \mathrm{cm}{ }^{-1}$, corresponding to a strong EFISH contribution. Using this calibration, the EFISH intensity deduced from the CP modeling can be related to a negative fixed charge density of $Q_{f}=2.5 \times$ $10^{11} \mathrm{~cm}^{-2}$ for the as-deposited $11 \mathrm{~nm}$ thick $\mathrm{Al}_{2} \mathrm{O}_{3}$ film, whereas after anneal $Q_{f}$ has increased to $5.4 \times 10^{12} \mathrm{~cm}^{-2}$ for this sample. These values, which are in good agreement with results obtained by conventional capacitancevoltage analysis [7,32], indicate that the field-effect passivation improves significantly upon anneal.

In Fig. 3(c) the SHG spectrum for p-polarized fundamental and SHG radiation is shown for the $84 \mathrm{~nm}$ thick a$\mathrm{SiN}_{x}: \mathrm{H}$ film on $\mathrm{Si}(100)$. This spectrum also shows a distinct resonance around $3.4 \mathrm{eV}$ which indicates again that $c-\mathrm{Si}$ interband transitions at the $E_{0} / E_{1}$ critical point (CP) dominate the SHG response. The data can be fitted very well when taking into account two contributions consisting of a Si-Si interface contribution at $3.32 \pm 0.01 \mathrm{eV}$ and EFISH contribution at $3.419 \pm 0.007 \mathrm{eV}$. The EFISH contribution is clearly dominant and the parameters of the fit are listed in Table I. The phase difference between the contribution due to the Si-Si interface bonds and the EFISH contribution is $\sim 0$, indicating a negatively charged Si SCR and therefore positive charge in the a-SiN $\mathrm{N}_{\mathrm{x}}: \mathrm{H}$ film. Using the aforementioned calibration data, the EFISH intensity deduced from the $C P$ modeling can be related to a fixed charge density of $Q_{f}=1.6 \times 10^{12} \mathrm{~cm}^{-2}$. The presence of positive charge in $a-\mathrm{SiN}_{x}: \mathrm{H}$ is well known and also the value of $Q_{f}$ is within the range typically reported for a$\mathrm{SiN}_{x}: \mathrm{H}$ yielding good surface passivation of $\mathrm{c}-\mathrm{Si}$ $[33,34,35]$. These results corroborate therefore the SHG analysis and confirm that an annealed $\mathrm{Al}_{2} \mathrm{O}_{3}$ film has a higher level of fixed charges than $a-\mathrm{SiN}_{x}: \mathrm{H}$ and that the fixed charges have the opposite polarity. Consequently, the higher fixed charge density in $\mathrm{Al}_{2} \mathrm{O}_{3}$ and the related higher level of electric field induced surface passivation explains the fact that $\mathrm{Al}_{2} \mathrm{O}_{3}$ outrules the level of surface passivation obtained with $a-\mathrm{SiN}_{x}: \mathrm{H}$. However, we also want to stress that there are clear indications that the chemical passivation by $\mathrm{Al}_{2} \mathrm{O}_{3}$ is also more effective than for $a-\mathrm{SiN}_{x}: \mathrm{H}[8,19]$.

\section{CONCLUSIONS}

$\mathrm{Al}_{2} \mathrm{O}_{3}$ and $a-\mathrm{SiN}_{x}: \mathrm{H}$ thin films deposited on $\mathrm{Si}(100)$ have been studied by spectroscopic SHG. The plasmaassisted $\mathrm{ALD} \mathrm{Al}_{2} \mathrm{O}_{3}$ films contain fixed charge with a negative polarity and with a density increasing from $\sim 10^{11}$ $\mathrm{cm}^{-2}$ before anneal to $10^{12}-10^{13} \mathrm{~cm}^{-2}$ after anneal. The "fired" PECVD a-SiN $\mathrm{N}_{\mathrm{x}} \mathrm{H}$ film contains a positive fixed charge with a density of $1.6 \times 10^{12} \mathrm{~cm}^{-2}$. These experiments confirm therefore that the $c$-Si passivation properties of $\mathrm{Al}_{2} \mathrm{O}_{3}$ and $a-\mathrm{SiN}_{x}: \mathrm{H}$ can be contributed to an effective electric field induced surface passivation effect. Moreover, for annealed $\mathrm{Al}_{2} \mathrm{O}_{3}$ the excellent passivation properties recently observed are a result of the increase in the internal electric field after the anneal while also an additional reduction of interface defect seems to be important $[8,19]$.

The results demonstrate the feasibility of using SHG for contactless investigation of electric field effect induced passivation mechanisms of $c$-Si. Importantly, the technique can in principle also be applied in situ and during processing. This kind of analysis is inaccessible by conventional techniques such as capacitance-voltage measurements, while the SHG studies do not require a minimum film thickness. Finally, we want to note that the SHG technique was recently also successfully employed for in situ studies on the growth of amorphous and epitaxial silicon films on $c-S i[36,37,38]$, a subject that is of high relevance for the passivation of $c$-Si surfaces by a-Si:H films.

\section{ACKNOWLEDGMENTS}

The authors thank W. Keuning for the $\mathrm{Al}_{2} \mathrm{O}_{3}$ depositions, and M.J.F. van de Sande, J.F.C. Jansen, J.J.A Zeebregts, and R.F. Rumphorst for their skillful technical assistance. OTB Solar is thanked for providing the a-SiN $\mathrm{N}_{x}: \mathrm{H}$ film. This work was supported by the Netherlands Foundation for Fundamental Research on Matter (FOM) and the Netherlands Organization for Scientific Research (NWO). 


\section{REFERENCES}

* Now with: Solar Energy Research Institute of Singapore, 4 Engineering Drive 3, 117576 Singapore

[1] G. Agostinelli, A. Delabie, P. Vitanov, Z. Alexieva, H.F.W. Dekkers, S. de Wolf, and G. Beaucarne, Sol. Energy Mater. Sol. Cells 90, 3438 (2006).

[2] M.J. Chen, Y.T. Shih, M.K. Wu, and F.Y. Tsai, J. Appl. Phys. 101, 033130 (2007).

[3] B. Hoex, S.B.S. Heil, E. Langereis, M.C.M. van de Sanden, and W.M.M. Kessels, Appl. Phys. Lett. 89, 042112 (2006).

[4] B. Hoex, J. Schmidt, R. Bock, P.P Altermatt, M.C.M. van de Sanden, and W.M.M. Kessels, Appl. Phys. Lett. 91, 112107 (2007).

[5] J. Schmidt, A. Merkle, R. Brendel, B. Hoex, M.C.M. van de Sanden, and W.M.M. Kessels, Progr. Photovoltaics 16, 461 (2008).

[6] J. Benick, B. Hoex, M.C.M. van de Sanden, W.M.M. Kessels, O. Schultz, and S. Glunz, Appl. Phys. Lett. 92, 253504 (2008).

[7] B. Hoex, J. Schmidt and P. Pohl, M.C.M. van de Sanden, and W.M.M. Kessels, J. Appl. Phys. 104, 044903 (2008).

[8] B. Hoex, J.J.H. Gielis, M.C.M. van de Sanden, and W.M.M. Kessels, J. Appl. Phys. 104, 113703 (2008).

[9] T.F. Heinz, Second-order Nonlinear Optical Effects at Surfaces and Interfaces, in: Nonlinear Surface Electromagnetic Phenomena, edited by H.E. Ponath and G.I. Stegeman (Elsevier, Amsterdam, 1991) .

[10] O.A. Aktsipetrov, A.A. Fedyanin, E.D. Mishina, A.N. Rubtsov, C.W. van Hasselt, M.A.C. Devillers, and Th. Rasing, Phys. Rev. B 54, 1825 (1996).

[11] J.G. Mihaychuk, J. Bloch, Y. Liu, and H.M. van Driel, Opt. Lett. 20, 2063 (1995).

[12] J. Bloch, J.G. Mihaychuk, and H.M. van Driel, Phys. Rev. Lett. 77, 920 (1996).

[13] G. Lüpke, Surf. Sci. Rep. 35, 75 (1999).

[14] Z. Marka, R. Pasternak, S.N. Rashkeev, Y. Jiang, S.T. Pantelides, N.H. Tolk, P.K. Roy, and J. Kozub, Phys. Rev. B 67, 045302 (2003).

[15] Y.D. Glinka, W. Wang, S.K. Singh, Z. Marka, S.N. Rashkeev, Y. Shirokaya, R. Albridge, S.T. Pantelides, N.H. Tolk, and G. Lucovsky, Phys. Rev. B. 65, 193103 (2002).

[16] V. Fomenko, E.P. Gusev, E. Borguet, J. Appl. Phys. 97, 083711 (2005).

[17] R. Carriles, J. Kwon, Y.Q. An, M.C. Downer, J. Price, and A.C. Diebold, Appl. Phys. Lett. 88, 161120 (2006).

[18] R. Carriles, J. Kwon, Y.Q. An, L. Sun, S.K. Stanley, J.G. Ekerdt, M.C. Downer, J. Price, T. Boeskce, and A.C. Diebold, J. Vac. Sci. Technol. B 24, 2160 (2006).

[19] J.J.H. Gielis, B. Hoex, M.C.M. van de Sanden, and W.M.M. Kessels, J. Appl. Phys. 104, 073701 (2008).

[20] J.L. van Hemmen, S.B.S. Heil, J.H. Klootwijk, F. Roozeboom, C.J. Hodson, M.C.M. van de Sanden, and W.M.M. Kessels, J. Electrochem. Soc. 154, G165 (2007).
[21] B. Hoex, A.J.M. van Erven, R.C.M. Bosch, W.T.M. Stals, M.D. Bijker, P.J. van den Oever, W.M.M. Kessels, M.C.M. van de Sanden, Prog. in Photovolt.: Res. Appl. 13, 705 (2005).

[22] J.J.H. Gielis, P. Gevers, I.M.P. Aarts, M.C.M. van de Sanden, and W.M.M. Kessels, J. Vac. Sci. Technol. A 26, 1519 (2008).

[23] W. Daum, H.-J. Krause, U. Reichel, and H. Ibach, Phys. Rev. Lett. 71, 1234 (1993).

[24] J.I. Dadap, Z. Xu, X.F. Hu, M.C. Downer, N.M. Russell, J.G. Ekerdt, and O.A. Aktsipetrov, Phys. Rev. B 56, 13367 (1997).

[25] G. Erley, R. Butz, and W. Daum, Phys. Rev. B 59, 2915 (1999).

[26] P. Lautenschlager, M. Garriga, L. Viña, and $M$. Cardona, Phys. Rev. B 36, 4821 (1987).

[27] G. Erley, and W. Daum, Phys. Rev. B 58, R1734 (1998).

[28] A. Rumpel, B. Manschwetus, G. Lilienkamp, H. Schmidt, and W. Daum, Phys. Rev. B 74, 081303 (2006).

[29] W. Moench, P. Koke, S. Krueger, J. Vac. Sci. Tech. 19, 313 (1981).

[30] S.M. Sze, Physics of semiconductor devices (Wiley, New York, 1981).

[31] J.A. Aboaf, D.R. Kerr, and E. Bassous, J. Electrochem. Soc. 120, 1103 (1973).

[32] D. Hoogeland, K.B. Jinesh, F. Roozeboom, W.F.A. Besling, W. Keuning, M.C.M. van de Sanden, W.M.M. Kessels, to be published (2009).

[33] J.R. Elmiger, R. Schieck, and M. Kunst, J. Vac. Sci. Technol. A 15, 2418 (1997).

[34] R. Hezel and K. Jaeger, J. Electrochem. Soc. 136, 518 (1989).

[35] S. Dauwe, J. Schmidt, A. Metz, and R. Hezel, Proceedings of the $29^{\text {th }}$ IEEE Photovoltaic Specialist Conference, New Orleans (IEEE, Piscataway, NJ, 2002), p. 162.

[36] J.J.H. Gielis, P.J. van den Oever, M.C.M. van de Sanden, and W.M.M. Kessels, Appl. Phys. Lett. 90, 202108 (2007).

[37] J.J.H. Gielis, P.M. Gevers, A.A.E. Stevens, H.C.W. Beijerinck, M.C.M. van de Sanden, and W.M.M. Kessels, Phys. Rev. B 74, 165311 (2006).

[38] J.J.H. Gielis, B. Hoex, P.J. van den Oever, M.C.M. van de Sanden, and W.M.M. Kessels, Thin Solid Films 517, 3456 (2009). 